\title{
Faktor-Faktor Yang Mempengaruhi Penyapihan Bayi Umur Kurang Dari 6 Bulan Melalui Studi Cross Section
}

\author{
Dahniar $^{1^{*}}$, Nurdiana ${ }^{2}$, Abdul Halim ${ }^{3}$ \\ ${ }^{1,2}$ Prodi D III Kebidanan FKIK Univ. Muhammadiyah, Makassar, Indonesia \\ ${ }^{3}$ Prodi D III Keperawatan FKIK Univ. Muhammadiyah, Makassar, Indonesia \\ * Corresponding author, email: dahniar@unismuh.ac.id
}

\begin{abstract}
Weaning too early can affect the growth of the baby and the mother often ignores the nutritional needs of the baby. In addition, malnutrition is more common today than during the first 4-6 months of life. This is because many families do not understand the special needs of babies and are unable to provide food with good nutritional value. The type of research used is a survey with a cross sectional study approach. The population is all mothers who have babies aged 6 months and the sample is all mothers who have babies aged 6 months. The sampling technique was simple random sampling. The results showed that there was a significant effect between mothers who did weaning for less than 6 months with education $=0.006$. There is a significant effect between mothers who do weaning for less than 6 months with employment status = 0.008. There is a significant effect between mothers who do weaning less than 6 months with birth spacing $=0.007$.
\end{abstract}

Keywords: Baby Less 6 Months, Malnutrition, Weaning.

\begin{abstract}
Abstrak
Penyapihan yang terlalu awal dapat mempengaruhi pertumbuhan bayi dan ibu sering mengabaikan kebutuhan gizi bayi. Selain itu, malnutrisi lebih sering terjadi pada masa kini ketimbang periode 4-6 bulan pertama kehidupan. Hal itu disebabkan karena banyak keluarga yang tidak mengerti kebutuhan khusus bayi dan tidak mampu menyediakan makanan yang bernilai gizi baik. Jenis penelitian yang digunakan adalah survey dengan pendekatan cross sectional study. Populasi adalah semua ibu yang memiliki bayi umur $\leq 6$ bulan dan sampel adalah semua ibu yang memiliki bayi umur $\leq 6$ bulan dengan teknik pengambilan sampel secara simple random sampling. Hasil penelitian menunjukkan bahwa ada pengaruh yang signifikan antara ibu yang melakukan penyapihan kurang dari 6 bulan dengan pendidikan $\rho=0,006$. Ada pengaruh yang signifikan antara ibu yang melakukan penyapihan kurang dari 6 bulan dengan status pekerjaan $\rho=0,008$. Ada pengaruh yang signifikan antara ibu yang melakukan penyapihan kurang adri 6 bulan dengan jarak kelahiran $\rho=0,007$.
\end{abstract}

Kata Kunci: Bayi Kurang 6 Bulan, Gizi Buruk, Penyapihan.

\section{Pendahuluan}

ASI eksklusif adalah pemberian ASI sedini mungkin setelah persalinan, diberikan tanpa jadwal dan tidak diberi makanan lain, walaupun hanya air putih, sampai bayi berumur 6 bulan. Setelah 6 bulan, bayi mulai dikenalkan dengan makanan lain dan tetap diberikan ASI sampai bayi berumur dua tahun [1]. Alam telah menyediakan makanan yang paling sesuai untuk bayi, yaitu ASI. Bagi anak, menerima ASI merupakan sebuah

Estimasi: Journal of Statistics and Its Application

e-ISSN: 2721-3803, p-ISSN: 2721-379X

http://journal.unhas.ac.id/index.php/ESTIMASI 
kebutuhan yang tak boleh terputus. Konvensi Hak-Hak Anak tahun 1990 antara lain menegaskan bahwa tumbuh kembang secara optimal merupakan salah satu hak anak, yang berarti selain ASI merupakan kebutuhan, juga merupakan hak asasi bayi yang harus dipenuhi oleh orang tuanya [2].

Modal dasar pembentukan manusia berkualitas di mulai sejak bayi dalam kandungan disertai dengan pemberian ASI sejak usia dini terutama pemberian ASI eksklusif [3]. Pertumbuhan dan perkembangan bayi terus berlangsung sampai dewasa. Proses tumbuh kembang ini dipengaruhi oleh makanan yang di berikan pada anak. Makanan yang paling sesuai untuk bayi adalah ASI, karena ASI memang diperuntukkan bagi bayi sebagai makanan pokok bayi, yang mengandung hampir semua zat gizi yang diperlukan oleh bayi dengan konsentrasi yang sesuai dengan kebutuhan bayi. Suatu penelitian terhadap 179 orang ibu yang menyusui dihasilkan $61 \%$ diantaranya tetap menyusui saat mengetahui dirinya hamil lagi, dan 38\% dari jumlah it uterus menyusui bersama kakaknya [4].

Bayi berhenti menyusu pada ibu berarti terputus hubungan kasih sayang antara bayi dan ibunya. Keadaan tersebut sering membawa akibat buruk terhadap bayi apalagi bila penyapihan dilakukan secara mendadak. Selama bayi minum ASI sedikit kemungkinan penyakit infeksi saluran pencernaan dengan penyapihan kemungkinan penyakit infeksi terutama pada saluran pencernaan. Hal tersebut dapat disebabkan karena kemungkinan kontaminasi pada makanan bayi dapat terjadi sangat besar, baik pada waktu membuat, menyimpan atau memberi ASI [5].

Hasil survey Demografi dan Kesehatan Indonesia (SDKI) 2002-2003 tentang pemberian ASI eksklusif pada bayi berumur 2 bulan hanya 64\%. Presentase tersebut menurun seiring dengan bertambahnya usia bayi yaitu $46 \%$ pada bayi usia 2-3 bulan, sekitar $14 \%$ pada bayi usia $4-5$ bulan dan $13 \%$ bayi dibawah umur 2 bulan telah diberi susu formula [6]. Dari beberapa penelitian, banyak sekali para ibu yang menyapih anaknya terlalu cepat yaitu pada usia kurang dari 1 tahun terutama bagi ibu - ibu yang bekerja, sedangkan penyapihan yang terlalu awal dapat mempengaruhi pertumbuhan bayi ibu sering mengabaikan kebutuhan gizi bayi [4].

Permasalahan malnutrisi lebih sering terjadi pada masa kini ketimbang periode 4-6 bulan pertama kehidupan. Hal tersebut biasanya disebabkan karena tidak sedikit keluarga yang tidak mengerti kebutuhan khusus bayi, tidak mampu menyediakan makanan yang bernilai gizi baik. Di berbagai tempat, kini kebiasaan makan anak-anak yang tradisional yang secara nalar dianggap memuaskan tidak lagi dapat dilanjutkan karena urbanisasi, tatanan baru keluarga, dan perubahan pola kerja wanita [4]. Berdasarkan uraian tersebut, penulis meneliti faktor-faktor yang mempengaruhi penyapihan pada bayi umur kurang dari 6 bulan di RW 08 Kelurahan Tamamaung Kecamatan Panakukang Makassar Tahun 2014. 


\section{Material dan Metode}

Penelitian yang digunakan adalah pendekatan cross sectional study. Tempat penelitian di laksanakan di RW 08 Kelurahan Tamamaung Kecamatan Panakukang Makassar. Kelurahan ini merupakan wilayah kerja Puskesmas Tamamaung Makassar. Populasi dalam penelitian ini adalah semua ibu yang memiliki Bayi umur kurang dari 6 bulan di RW 08 Kelurahan Tamamaung sebanyak 415 ibu. Adapun sampel penelitian adalah semua ibu yang memiliki bayi berumur kurang dari 6 bulan di RW 08 Kelurahan Tamamaung. Sampel penelitian diambil dengan cara simple random sampling yaitu semua populasi dijadikan sampel dalam penelitian ini yaitu semua ibu yang memilki bayi dibawah umur kurang dari 6 bulan dengan besaran sampel dihitung menggunakan rumus sederhana yaitu [6] :

$$
\mathrm{n}=\frac{\mathrm{Z}^{2} \cdot \mathrm{P} \cdot \mathrm{Q}}{\mathrm{d}^{2}}
$$

Keterangan :

$\mathrm{n}=$ besar sampel

$\mathrm{P}=$ proporsi sifat tertentu yang di perkirakan terjadi dari populasi (bila tidak diketahui ditetapkan sebesar 0,5)

$\mathrm{Z}=$ standar deviasi normal pada derajat kepercayaan $(1,96)$

$\mathrm{d}=$ tingkat kemakmuran digunakan $(0,1)$

$\mathrm{Q}=(1-\mathrm{p})$

Selanjutnya didapatkan besaran sampel sebagai berikut:

$$
\begin{aligned}
& \mathrm{n}=\frac{1,96^{2} \cdot 0,5 \cdot(1-0,5)}{0,1^{2}} \\
& \mathrm{n}=\frac{3,84 \cdot 0,5 \cdot 0,5}{0,01} \\
& \mathrm{n}=\frac{0,96}{0,01} \\
& \mathrm{n}=96
\end{aligned}
$$

Hal ini berarti bahwa besarnya sampel yaitu 96 ibu yang mempunyai bayi umur kurang dari 6 bulan. Selanjutnya, analisa yang dilakukan untuk mengetahui variabel dependen dan independen dalam bentuk tabulasi silang (cross tabulation) dilakukan melalui uji statistic $c h i-$ square dalam analisis bivariat.

\section{Hasil dan Diskusi}

\subsection{Hasil}

1 Analisis Univariat

Data identitas sampel mencakup status pendidikan, status pekerjaan dan jarak kelahiran. Distribusi frekuensi untuk status pendidikan ibu ditunjukkan melalui Tabel 1 dan diperoleh hasil bahwa sekitar 69 orang atau 71,88\% ibu yang memiliki pendidikan kategori tinggi. Adapun sisanya, yaitu 27 orang atau sekitar 28,12\% ibu yang memiliki Pendidikan rendah. Hasil ini menunjukkan bahwa rata-rata pendidikan ibu yang menyusui 
di RW 08 Kelurahan Tamamaung Kecamatan Panakukang Makassar masuk ke dalam kategori tinggi.

Selanjutnya, distribusi frekuensi ibu berdasarkan status pekerjaan ditunjukkan pada Tabel 2 dan diperoleh hasil bahwa antara ibu bekerja dengan ibu tidak bekerja memiliki frekuensi yang seimbang yaitu 50\%. Adapun, kondisi jarak kelahiran dari ibu menyusui di RW 08 Kelurahan Tamamaung Kecamatan Panakukang Makassar dapat dilihat pada Tabel 3. Distribusi frekuensi menunjukkan bahwa lebih banyak ibu yang memiliki jarak kelahiran kurang dari 2 tahun yaitu sekitar 66,67\%.

Tabel 1. Distribusi Frekuensi Ibu Melakukan Penyapihan Pada Bayi Umur Kurang Dari 6 Bulan Berdasarkan Status Pendidikan Ibu Di RW 08 Kelurahan Tamamaung

\begin{tabular}{ccc}
\hline Pendidikan & Frekuensi & Persentase \\
\hline Tinggi & 69 & 71,88 \\
Rendah & 27 & 28,12 \\
\hline Jumlah & 96 & 100,00 \\
\hline
\end{tabular}

Sumber: Olah data, 2021

Tabel 2. Distribusi Frekuensi Ibu Melakukan Penyapihan Pada Bayi Umur Kurang Dari 6 Bulan Berdasarkan Status Pekerjaan Ibu Di RW 08 Kelurahan Tamamaung

\begin{tabular}{ccc}
\hline Status Pekerjaan & Frekuensi & Persentase \\
\hline Ya & 48 & 50,00 \\
Tidak & 48 & 50,00 \\
\hline Jumlah & 96 & 100,00 \\
\hline
\end{tabular}

Sumber: Olah data, 2021

Tabel 3. Distribusi Frekuensi Ibu Melakukan Penyapihan Pada Bayi Umur Kurang Dari 6 Bulan Berdasarkan Status Jarak Kelahiran Ibu Di RW 08 Kelurahan Tamamaung Kecamatan

\begin{tabular}{ccc}
\hline Jarak Kelahiran & Frekuensi & Persentase \\
\hline$\leq 2$ tahun & 64 & 66,67 \\
$>2$ tahun & 32 & 33,33 \\
\hline Jumlah & 96 & 100,00
\end{tabular}

Sumber: Olah data, 2021

2 Analisis Bivariat

Analisa bivariat dilakukan untuk mengetahui pengaruh antara pendidkan, pekerjaan, jarak kelahiran dengan ibu yang melakukan penyapihan kurang dari umur 6 bulan dengan menggunakn uji statistic Chi-Square $\left(\mathrm{X}^{2}\right)$. 
Tabel 4. Analisis Pengaruh Pendidikan dengan penyapihan pada bayi umur kurang dari 6 bulan Di RW 08 Kelurahan Tamamaung

\begin{tabular}{ccccc}
\hline Pendidikan & \multicolumn{2}{c}{$\begin{array}{c}\text { Penyapihan bayi umur } \\
<6 \text { bulan }\end{array}$} & Jumlah & $\mathrm{X}^{2}$ \\
\cline { 2 - 3 } & Ya & Tidak & & \\
\hline Rendah & 61 & 8 & 69 & 0,006 \\
Tidak & 17 & 10 & 27 & \\
Jumlah & 78 & 18 & 96 & \\
\hline
\end{tabular}

Sumber: Olah data, 2021

Tabel 5. Analisis Pengaruh Status Pekerjaan dengan penyapihan pada bayi umur kurang dari 6 bulan Di RW 08 Kelurahan Tamamaung

\begin{tabular}{ccccc}
\hline \multirow{2}{*}{ Pendidikan } & \multicolumn{2}{c}{$\begin{array}{c}\text { Penyapihan bayi umur }<6 \\
\text { bulan }\end{array}$} & Jumlah & $X^{2}$ \\
\cline { 2 - 3 } & \multicolumn{2}{c}{ Ya } & Tidak & \\
\hline Bekerja & 44 & 4 & 48 & 0,008 \\
Tidak bekerja & 34 & 14 & 48 & \\
Jumlah & 78 & 18 & 96 & \\
\hline
\end{tabular}

Sumber: Olah data, 2021

Tabel 4 menunjukkan hasil analisis hubungan ibu melakukan penyapihan pada bayi umur kurang dari 6 bulan dengan pendidikan melalui uji chi-square dengan taraf signifikan $(\alpha)=5 \%$, di dapatkan $\rho=0,006$. Hal ini berarti Ha diterima atau dapat disimpulkan bahwa ada pengaruh yang signifikan antara pendidikan dengan penyapihan pada bayi umur kurang dari 6 bulan.

Hasil analisis pada Tabel 5 menunjukkan hubungan ibu melakukan penyapihan pada bayi umur kurang dari 6 bulan dengan status pekerjaan melalui uji chi-square dengan taraf signifikan $(\alpha)=5 \%$, di dapatkan $\rho=0,008$. Hal ini berarti Ha diterima atau dapat disimpulkan bahwa ada pengaruh yang signifikan antara status pekerjaan dengan penyapihan pada bayi umur kurang dari 6 bulan.

Tabel 6. Analisis Pengaruh Jarak Kelahiran dengan penyapihan pada bayi umur kurang dari 6 bulan Di RW 08 Kelurahan Tamamaung

\begin{tabular}{ccccc}
\hline Jarak Kelahiran & \multicolumn{2}{c}{$\begin{array}{c}\text { Penyapihan bayi umur }<6 \\
\text { bulan }\end{array}$} & Jumlah & $\mathrm{X}^{2}$ \\
\cline { 2 - 3 } & Ya & Tidak & & \\
\hline$\leq 2$ Tahun & 57 & 7 & 64 & 0,007 \\
$>$ 2 Tahun & 21 & 11 & 32 & \\
Jumlah & 78 & 18 & 96 & \\
\hline
\end{tabular}

Sumber: Olah data, 2021 
Tabel 6 menunjukkan hasil analisis hubungan ibu melakukan penyapihan pada bayi umur kurang dari 6 bulan dengan jarak kelahiran melalui uji chi-square dengan taraf signifikan $(\alpha)=5 \%$, di dapatkan $\rho=0,007$. Hal ini berarti Ha diterima atau dapat disimpulkan bahwa ada pengaruh yang signifikan antara jarak kelahiran dengan penyapihan pada bayi umur kurang dari 6 bulan.

\subsection{Diskusi}

1. Hubungan status pendidikan dengan penyapihan pada bayi umur $<6$ bulan.

Hasil penelitian menunjukkan bahwa dari 28 ibu yang melakukan penyapihan pada bayi umur $\leq 6$ bulan terdapat 19 orang $(68,00 \%)$ yang berpendidikan tinggi sedangkan pendidikan rendah terdapat 9 orang $(32,00 \%)$. Hal ini menunjukkan bahwa lebih banyak ibu yang pendidikan tinggi yang melakukan penyapihan bayi daripada pendidikan rendah. Pengertian pendidikan adalah suatu proses belajar mengajar dalam bidang pengetahuan, keterampilan, dan sikap professional, yang dilaksanakan oleh lembaga pendidikan yang telah diakreditasi oleh lembaga yang berwenang. Pendidikan yang dimaksud adalah pendidikan formal dan pendidikan non formal. Pendidikan formal adalah jalur pendidikan yang terstruktur dan berjenjang dan terdiri atas SD, SLTP, SLTA dan perguruan tinggi. Pendidikan non formal adalah jalur pendidikan di luar pendidikan formal yang dapat dilaksanakan secara terstruktur dan berjenjang.

Kesehatan/status gizi bayi/anak serta kelangsungan hidupnya akan lebih baik pada ibu-ibu yang berpendidikan rendah, hal ini karena seorang ibu yang berpendidikan tinggi akan memiliki pengetahuan yang luas serta kemampuan untuk menerima informasi lebih tinggi [7]. Hasil penelitian ini menunjukkan bahwa lebih banyak ibu yang yang memiliki pendidikan tinggi dan ini dapat disebabkan karena seorang ibu yang berpendidikan tinggi akan memiliki pengetahuan yang luas serta kemampuan untuk menerima informasi lebih tinggi.

2. Hubungan status pekerjaan dengan penyapihan pada bayi umur $<6$ bulan.

Hasil penelitian menunjukkan bahwa ibu yang melakukan penyapihan pada bayi umur kurang dari 6 bulan berdasarkan status pekerjaan yang bekerja 44 orang dan tidak menyapih kurang dari 6 bulan 4 orang, sedangkan tidak bekerja yang melakukan penyapihan 34 orang dan tidak melakukan penyapihan 14 orang. Hasil analisis pengaruh ibu melakukan penyapihan pada bayi umur kurang dari 6 bulan dengan status pekerjaan melalui uji chi-square dengan taraf signifikan $(\alpha)=5 \%$, di dapatkan $\rho=0,008$. Hal ini berarti Ha diterima atau dapat disimpulkan bahwa ada pengaruh yang signifikan antara status pekerjaan dengan penyapihan pada bayi umur kurang dari 6 bulan.

Pekerjaan adalah setiap kegiatan yang menghasilkan barang atau jasa bagi diri sendiri atau orang lain,baik orang yang melakukan dibayar atau tidak. Suatu program pemberian ASI pada pekerja wanita mempunyai dampak positif tidak hanya pekerja tersebut tetapi juga untuk keluarganya, masyarakat dan terutama untuk organisasi/perusahaan dimana 
wanita/ibu bekerja. Untuk keberhasilan program ASI bagi pekerja wanita perlu adanya dukungan dari semua pihak khususnya pihak manajemen. Banyak ibu yang melakukan penyapihan lebih dini karena alasan-alasan tertentu.Seperti keterbatasan waktu karena ibu harus bekerja atau karena produksi ASI yang tidak lancer atau anak tidak mau disapih.Namun ibu yang bekerja cenderung melakukan penyapihan lebih cepat.

Hasil penelitian tersebut menunjukkan bahwa lebih banyak ibu yang bekerja. Sedangkan menurut teori banyak ibu yang melakukan penyapihan lebih dini karena alasan-alasan tertentu, seperti keterbatasan waktu karena ibu harus bekerja atau karena produksi ASI yang tidak lancar atau anak tidak mau disapih. Namun ibu yang bekerja cenderung melakukan penyapihan lebih cepat.

3. Hubungan jarak kelahiran dengan penyapihan pada bayi umur $<6$ bulan .

Hasil penelitian menunjukkan bahwa ibu yang melakukan penyapihan pada bayi umur kurang dari 6 bulan berdasarkan jarak kelahiran yang $\leq 2$ tahun sebanyak 57 orang dan tidak menyapih kurang dari 6 bulan 7 orang, sedangkan jarak kelahiran $>2$ tahun sebanyak 21 orang dan tidak melakukan penyapihan 11 orang. Hasil analisis hubungan ibu melakukan penyapihan pada bayi umur kurang dari 6 bulan dengan jarak kelahiran melalui uji chi-square dengan taraf signifikan $(\alpha)=5 \%$, di dapatkan $\rho=$ 0,007. Hal ini menunjukkan Ha diterima atau dapat disimpulkan bahwa ada pengaruh yang signifikan antara jarak kelahiran dengan penyapihan pada bayi umur kurang dari 6 bulan.

Jarak kelahiran dalam arti khusus yaitu jarak antara anak pertama dan kedua [7]. Bahaya terhadap seorang anak timbul apabila terjadi kelahiran lagi sedangkan anak sebelumnya masih minum ASI, sehingga perhatian ibu beralih pada anak yang baru lahir. Terhentinya pemberian ASI merupakan faktor pendorong terjadinya gizi buruk. Hasil penelitian menunjukkan sama dengan umur 2 tahun dan $<2$ tahun. Bahaya terhadap seorang anak timbul apabila terjadi kelahiran lagi sedangkan anak sebelumnya masih minum ASI, sehingga perhatian ibu beralih pada anak yang baru lahir.

\section{Kesimpulan}

Berdasarkan hasil penelitian dan analisa data tentang faktor-faktor yang mempengaruhi ibu melakukan penyapihan pada bayi umur kurang dari 6 bulan di RW 08 Kelurahan Tamamaung dapat disimpulkan bahwa ada hubungan yang signifikan pendidikan dengan penyapihan pada bayi umur kurang dari 6 bulan dan nilai $\rho=0,006$. Untuk faktor pekerjaan, ada hubungan yang signifikan status pekerjaan dengan penyapihan pada bayi umur kurang dari 6 bulan dan nilai $\rho=0,008$. Selanjutnya, untuk faktor jarak kelahiran, ada hubungan yang signifikan jarak kelahiran dengan penyapihan pada bayi umur kurang dari 6 bulan dan $\rho=0,007$.

\section{Daftar Pustaka}

[1] Purwanti, S. Gizi Bayi dan Balita, TIM, Jakarta, 2004. 
[2] Badriul, B. Makanan Bayi Bergizi, Fitramaya, Yogyakarta, 2006.

[3] Sastroasmoro. Persiapan Laktasi \& Menyusui, FKUI, Jakarta, 2005.

[4] Jitowiyono, S. Asuhan Keperawatan Neonatus dan Anak, Muna Medika, Yogyakarta, 2010.

[5] Nadesul. Kapita Selekta ASI dan Menyusui, Balai Pustaka, Jakarta, 2000.

[6] Notoadmojo. Metode Penelitian, Balai Pustaka, Jakarta, 2005.

[7] Siregar, A. Gizi Balita, Rineka Cipta, Jakarta, 2004. 